\title{
9 Mediation Is Our Authenticity
}

\author{
Dagong Poetry and the Shijing in Translation
}

\author{
Lucas Klein
}

\begin{abstract}
This essay starts from the premise that a poem is a translational process: always, not just once it has been translated in the conventional sense. From there, the author complicates and reorients the authenticity claims that have been built into the discourse around both the ancient Shijing and Chinese migrant worker poetry today. He argues that these two poetries' many moments of intralingual, interlingual, and cultural translation constitute and reiterate each other - and that the recognition of this should place proper attention on the work and the art involved in each.
\end{abstract}

Keywords: Chinese poetry, translation, authenticity, Shijing, dagong poetry, cultural translation

Unlike most of the songs nowadays that are being written uptown in Tin Pan Alley - that's where most of the folk songs come from nowadays - this, this is a song ... this wasn't written up there. This was written somewhere down in the

United States. - Bob Dylan (1963)

I start from the premise that a poem is not an authenticity but a translational process - always, not just once it has been translated in the conventional sense. In Chinese poetry, the $c i$ (詞) that were popularized in the Song were first written as lyrics to foreign music, and the regulated verse (律 詩) that made tonal prosody definitive for Chinese poetics was devised in reaction to contact with Indic languages (see Mair and Mei 1991). And the paradigmatic English poem, the sonnet, came from Italian. Poems that reject

Van Crevel, Maghiel and Lucas Klein (eds.), Chinese Poetry and Translation:Rights and Wrongs. Amsterdam: Amsterdam University Press, 2019 DOI: $10.5117 / 9789462989948 \_C H O 9$ 
inspiration from other languages, meanwhile, are bound to draw from the past, translating via their acts of poetic updating. Understood as instances of cultural translation - from abroad or from history - much poetry can be read as taking part in the processes of nativization and foreignization that govern interlingual translation (see Klein 2018). But even aside from the well-known examples of genres, forms, and subject matter crossing geographical and temporal boundaries, a poem is a translational process because it involves the putting of thoughts and emotions into language. Even the most original and heartfelt poetic expression is a translation of feeling into a work of linguistic art.

The best argument for the premise that a poem is not an authenticity but a translational process is, I think, a good interlingual translation - one that brings out the translatedness of the source text. Attention to the approaches that underlie such translations will help explain and ease the epistemological distinction between premodern and modern Chinese poetry that is widely taken for granted, and it will help clarify the relationship between interlingual translation and cultural translation.

This point needs making because we have a habit in the study of Chinese literature to treat the object of our inquiry as authentic, and therefore as essentially untranslatable. As Rey Chow has put it, in sinology, "the practitioners of Chinese writing - or the Chinese practitioners of writing - are, in effect, read as ethnics, or natives, who are endowed with a certain primitive logic" $\left(1998,15^{-16}\right)$. Of course, those taking such an approach do in fact translate the Chinese poetry in question; what I mean is that for them the primary measure of translation lies in the loss of an authentic source. Chinese poetry and Western poetry, in this view, are ontologically separate, and so the truth and essence of Chinese poetry can never quite be captured in the rhetoric of a Western language. (If such translations are simply not very good, for them the lack of quality implies the "untranslatability" of the exalted source texts, as the sacred "originals" they are; for me, however, it implies a lack of appreciation of both the art and the work of the poetry in question).

The assumed untranslatability of Chinese poetry also contributes to the disciplinary divide between Chinese poetry's modern and premodern incarnations - and the notion that modern Chinese poetry is somehow less "Chinese" because less untranslatable (see Klein 2017, 7-9). If a recent Chinese poetic subgenre now offers a way past this disciplinary divide, it does so by providing a way back into authenticity and Chineseness: against the work of writers likely to be noted for their technique and relationship to international literary trends, migrant worker or "battlers" poetry, dagong shige (打工诗歌), tends to get treated as an unmediated expression of the Chinese 
authentic. As Maghiel van Crevel notes, dagong poetry is then understood to exhibit an "authentic poetry's sensitivity and relevance to social realities," which is linked to "literature's relation to national identity" and "a claim to Chineseness" based on "a somewhat unambiguous reading of the Book of Songs 詩經” from China's bronze age (2017a, 275). ${ }^{1}$ Echoing Chow on the "primitive logic," van Crevel elsewhere critiques the way the dagong poet has often been configured as a "noble savage" in the house of poetry (2019).

Such configurations only replay the divide of Chineseness along the axis of translation, with dismissals of how more typically literary poems are said to "translate themselves" (Owen 1990, 31), while dagong poetry's emphasis on "lived experience" (Goodman 2017, 112) raises "the old question of whether the translator is at liberty to 'improve the original'" (van Crevel $2017 \mathrm{~b}$ ). Might attention to the work of translation also close such divides?

Van Crevel has noted that dagong poetry "is often framed in a crude opposition of social significance (high) and aesthetic value (low) that might just not be the whole story" (2017c, par. 101; for further elaboration, see van Crevel 2019). Bringing the work of translation into this story should help alleviate such a crude opposition. Translating contexts here, the case of the workers who write dagong poetry is not unlike that of experimental Asian American poets, whom Dorothy Wang describes in Thinking Its Presence as facing a limited and limiting either-or when it comes to critical appreciation:

Whether critics focus solely on ethnic content in more mainstream Asian American poetry or ... ignore issues of race in avant-garde Asian American poetry and privilege the "purely" literary or formal (against the ethnic), the full complexity of Asian American poetry - and minority American poetry - has not been acknowledged.

$(2014,33)$

Wang shows how ethnicity and avant-garde poetry practice do not need to be at odds. Similarly, my aim here is to show how social significance and aesthetic value do not need to be so crudely opposed - but to make this point, I will focus on translation. I have elsewhere looked into the translingual influences on modern and medieval poetry in Chinese to argue that impressions of poetic Chineseness, from tonal prosody to allusions to the literary past, are a product of translation (2018). Here I will be looking

1 Rather than using either traditional or simplified characters throughout, in citations I follow the publication in question. Since I cite writers who use different translations for dagong poetry and for the Shijing, I will default to romanization in both cases. 
at authenticity claims on both sides of the link van Crevel points to - the Shijing and dagong poetry, in particular Eleanor Goodman's translations in the 2016 anthology Iron Moon - to argue that poetry can never stand outside translation.

Evidence for the necessity of such an argument can be found in Wang's own work, among other places. Writing about Asian American literature, she occasionally touches on Chinese poetry and translation in its many guises. In the back matter, she notes that "what many now consider 'pure' (Han) Chinese classical poetry was influenced by 'barbarian' cultures" - but then she adds a bibliography: "Critics who have written cogently on traditional Chinese poetry and its intersection with Western poetics include [Stephen] Owen, James J. Y. Liu, and Wai-lim Yip" (2014, 346n62). But what have these three said about Chinese poetry's intersection with Western poetics? In Wang's quotation of Liu and Yip to support her reading of Hong Kong-born American poet Marilyn Chin, they both demonstrate the ethnographic treatment of Chinese poetic language, ascribing to it the "primitive logic" which Chow critiques. The "omission of the subject" in classical Chinese poetic grammar, Liu says, gives Chinese poetry "an impersonal and universal quality, compared with which much Western poetry appears egocentric and earth-bound." For Yip, "the classical Chinese language, as it is used in poetry, is free from syntactical rigidities - having no articles, personal pronouns, verb declensions, or connective elements such as prepositions and conjunctions and being indeterminate in parts of speech," which he contrasts with "the predicative activities and habits of mind in Indo-European languages" (quoted in Wang 2014, 156-157). ${ }^{2}$ Not only do the passages cited by Wang recall the "primitive logic" ascribed to Chinese writing, they also undermine the notion of cultural translation for which Wang argues when citing their work.

And interlingual translation? In the book Wang cites, Owen notes that "Translators of Chinese often create their own vision of 'Chinese' literature as a whole, either articulated against English literature or as a possibility within it" (1996, xliii). Elsewhere he has written that translation requires us to

sacrifice Chinese poetics - the openness of relation between words, the parallel structures, the nonfictional poet speaking from a particular moment, moving with experience. But we will choose the best analogues from our own literature: the dramatic monologue, the confessional tradition, the diary. $(1985,125)$

2 Wang "take[s] issue with Liu's praise of the "universal," but her reasoning is race-based (Wang 2014, 156); see her elaboration on pp. 347-348n86. 
At once he ethnographizes Chinese poetics and writes against translation as anything but reiterating difference between "Chinese poetics" and "our literature."

James Liu presents a similar ontological division, played out in a typology of translation: there is the "poet-translator" and the "critic-translator," one translating for readers who "need to know how far a translation resembles the original and not simply how well it reads in English," the other for those who are "in no position to know, and perhaps do not care, how far a translation resembles the original" (1982, 37-38). This is the opposite of Wai-lim Yip's proposition, but Yip also begins with a stark division between Chinese and Indo-European capacities in writing things as they really are: "Until we disarm the tyrannical framing functions of the English language, the natural self in its fullest sentience cannot be released to maximum expressivity." Fortunately, however,

poets and philosophers in the West have already begun to question the framing of language, echoing in part the ancient Taoist critique of the restrictive and distorting activities of names and words and their powerwielding violence ... The[ir] syntactical innovations ... suddenly open up a new perceptual-expressive possibility in English, a new ambience whereby I can stage Chinese poetry according to its original operative dynamics rather than tailoring it to fit the Western procrustean bed.

(1997, xiv)

Modernist and postmodernist American poetry have saved the day, allowing Yip to present the world as it truly is - and as premodern Chinese poetics showed it to be! But while Yip holds out the possibility of comparability, and not just contrast, between Chinese poetry and certain modes of English poetics, such a possibility is established upon an essential difference between the linguistic epistemologies of East and West.

Thus, while Wang argues against ethnographizing Asian American poetry, that is how her sources for thinking on Chinese-English poetry translation treat Chinese poetics. Her work would have benefited from reflection on Zhang Longxi's point that theses such as Owen's, Liu's, and Yip's "put Chinese wen [文] and Western literature in an untenable opposition, a dichotomy between natural manifestation and human creation" $(2005,22)$. Yet it is telling that a scholar of literature should stumble when discussing not only translation, but the relationship between cultural translation and interlingual translation. Too often, when considering the relationship between literature and identity, we fail to think of, and to think through, translation. 
Well, what is the relationship between interlingual translation and cultural translation? Van Crevel distinguishes between cultural translation defined as what Susan Bassnett calls "translation understood figuratively as movements between cultures," on the one hand, and "[c]ulturally inflected interlingual translation," on the other, for which "Eleanor Goodman's textual, paratextual and epitextual translations of battlers poetry come to mind" (he also notes "[t]ranslational aspects of anthropological practice," but this is less relevant to the present discussion). In culturally inflected interlingual translation, the translator "acts on the awareness that interlingual translation is inherently a cultural affair that goes beyond linguistic re-expression, and that the texts in question are inextricable from their contexts in both the source language and the target language." In translational movements between cultures, translation is not necessarily about texts or languages but also or primarily about people, and "is associated with ... hybridity and in-betweenness, and with oppression, resistance and conflict" (2017a, 247-248). Yet how far are these two definitions from each other? Would Goodman's renditions of dagong poetry be possible without a broader awareness of translation understood figuratively as movements between cultures? Could translation be understood figuratively without the work of culturally inflected interlingual translations?

For van Crevel, "we stand to gain from letting [various types of cultural translation] operate alongside one another as the material permits or requires, respecting their distinction and being alert to moments of synergy" (van Crevel 2017a, 248). Here I will extend this awareness to look at assumptions underlying figuration itself and the role these assumptions have played in the construction of notions of Chineseness, authenticity, and the possibilities of translation. Figuration, for instance, is at stake in ideas that modern Chinese poetry is overly Western in its tropes, and that Chinese poetry is supposed to voice an authenticity that functions ethnographically yet inevitably calls translation into question.

Specifically, I look into van Crevel's point about dagong poetry's “authenticity" claims being borrowed from the authority of the Shijing, which grants dagong poetry "an easy edge over the avant-garde's generally cosmopolitan outlook" in current Chinese commentarial discourse (2017a, 275). While he problematizes the binary between "foreign" figuration and the Chinese "authentic," I am not convinced that he has resolved the positional tension between them. I will further the argument that interlingual translation and translation as a trope for movement between cultures require and reiterate each other, then, by drawing on a tradition of scholarship that has critiqued this division. The debates about the reading of the Shijing in this tradition 
of scholarship are important to the antifoundationalist foundation I need to lay out in order to discuss dagong poetry; as such, it is necessary to go through them in some detail. I will then lead this discussion into further consideration of culturally inflected interlingual translations of dagong poetry such as Goodman's. We are faced with a number of interrelated authenticity claims, and my attempt here is to show how they are linked and how translation can help us see their fallaciousness and our way past them.

\section{The Shijing in the midst of mediation}

In his critical commentary on dagong poetry, He Xuan 何轩 writes that his book "borrows the traditional Chinese method of commentary ... modelled on that of the Shijing by Mao Heng 毛亭 and Mao Chang 毛萇 in the Han dynasty of our nation" (2010, iv). Though He describes himself as engaged in a kind of cultural translation, mediating between dagong poets and scholars, clearly he has a sense of what van Crevel calls "the poet's personal experience" and "literature's relation to national identity" as underpinning an authentic Chineseness. He's focus on the poets' "authentic identity 'of the people” (地道“民间”身份) bears this out, as does his citation of Huang Zunxian's 黃遵憲 (1848-1905) famous line in relation to that identity: “They are a distinct collective of those living on the lower echelons of society. They survive by 'battling' it out on the lower echelons, and they try to create poetry according to the principle of 'My hand writes my mouth"” (我手寫我 口). He categorizes the poems in his anthology according to how workers encounter the “mind-body problem" (身心问题) in light of “the quality of 'poetry verbalizing intent"' (詩言志) - taken from the Mao Preface to the Shijing (2010, iv-v). The mind-body problem represents the dualism that the authentic Chineseness of the Shijing and dagong poetry is meant to resolve.

Yet He's simple association of the Shijing with the Mao commentaries demonstrates that as the commentaries were overturned, they were emptied of meaning. As Haun Saussy explains, this took place roughly a century ago: "The campaign to overturn the Mao Prefaces is May Fourth in a nutshell. (It is also a remarkable gesture of devotion to what seemed worth saving in the Confucian canon, despite all that the canon had been made to say)" (1993, 58). The Mao commentaries' mode is allegoresis, reading allegory into the poems. They were overturned because, as Zhang Longxi has written, allegoresis "is a strong interpretation that often ignores, or even does violence to, the letter of the text in order to make it fit within the framework of a religious, moral, political, or philosophical system" $(2005,86)$. By the early twentieth 
century, Saussy explains, "the immorality (in metropolitan eyes) of" much of the Shijing "requires that a new reading be superimposed on the literal meaning ... Reading the poems in their 'original sense' will restore" - so the argument goes - "the original autonomy of the village customs" (1993, 57). Today, according to Zhang,

Scholars and critics tend to see traditional commentaries as unwarranted moral and political overinterpretation imposed on poetry without considerations of its literal meaning or aesthetic values. "The susceptibility to allegorization in the traditional Shih Ching scholarship," as C. H. Wang puts it, "is a manifest distortion of this classic anthology, a distortion both of its generic character and of the original definition of shih in general."

$(2005,98)$

He Xuan says he models his exegesis after the Mao commentaries, but his method is not one of allegoresis. Rather than a metaphorical gloss superimposed on the text, the Mao commentaries have turned into a synecdoche for the text, in all its authenticity as the vox populi ancestor of dagong poetry.

Zhang and Saussy are debating "the metaphor problem" (see Hayot 2011, 97-99), for which the Shijing is the most common reference point. Saussy argues for the possibility of a Chinese poetic allegory, against statements such as C. H. Wang's, above, and claims by Owen and Pauline Yu that the "traditional Chinese reader had faith that poems were authentic presentations of historical experience" (Owen 1985, 57) because "[i]ndigenous Chinese philosophical traditions agree on a fundamentally monistic view of the universe," in contrast to "Western allegory," which "creates a hierarchical literary universe on two levels ... only one of which has ultimate primacy" (Yu 1987, 32, 21). For Saussy, this view denies the artistry of Chinese poetry. Zhang, for his part, believes in the possibility of Chinese allegory, though he argues against the Mao commentaries for a more "literal" understanding of the Shijing: "any figurative or allegorical meaning must be based on the literal sense of the text, and any use of poetry that does violence to that primary context would constitute a breaking of the poem's textual integrity" $(2005,92)$. Their debate has done much to change the discussion about the comparability of cultures and literatures - and, by extension, about translation.

Saussy's first book, The Problem of a Chinese Aesthetic, is usually noted for its first chapter (Chow 1998, 14-15; Hayot 2011, 98), which traces disbelief in Chinese allegory back to the European understanding of China born when Jesuit missionaries debated whether Confucian rites were "religious." Indeed, two earlier scholars in the West with an ethnographic approach to 
translation, Herbert Giles and Marcel Granet, were key links in the Shijing's chain of resignification (see Saussy 1993, 19-20). But the rest of the book lays out a productive argument for how we should understand allegory in the Shijing. The authors of the commentary were disciples of Xunzi 荀 子 - famous for stating that "People are bad by nature; what is good in them is made by effort” (人之性惡, 其善者偽也) (Xunzi 1988, 434) - so the "expressive thesis has to take second place to the prescriptive thesis ... What poetry 'expresses' is human nature, in which case it is evil; or it expresses the second nature of the sages, in which case its cause is not natural but artificial, emanating from a prescriptive sagely decree" (Saussy 1993, 105). The "authors of the Prefaces and commentaries are not afraid to praise their Book of Odes as a made thing, a product of interpretation ... The model for reading," then, "is work, the replacement of a given object by a made one" (118-119). To think otherwise is to fall for a "theory of poetic language that ... has nothing to say about work (which is not work unless it changes something)" (138). ${ }^{3}$ The focus on both art and work are also relevant to any consideration of translating dagong poetry.

Saussy's first monograph is only the first in a series to critique the notion of the authentic - to argue, instead, "that we are always in the midst of mediation, that mediation is our authenticity - whoever 'we' may be" (2001, 3). In his Great Walls of Discourse, he problematizes anew the hypothesis that all Chinese poems are true:

in the study of Chinese poetics, we find a case of incompatibility between the semantics of the quoted language and its place in a quoting syntax. The object-language must at least threaten to break through the metalanguage's syntactic frame, for one mission of such cultural comparison is to call into doubt the assumption that our meta-language (typologically "Western," "modern") enjoys a superordinate, theoretically capable, status and is entitled to determine what "true" means.

$(2001,60-61)$

In The Ethnography of Rhythm, he goes further, looking at the postulation of "oral literature" and its "implication that by 'oral' we must mean 'not written' ... that 'oral literature' is what the work originally (despite the passage of time) and really (despite the words on the page) is" (2016, 1-2).

3 To think otherwise, then, as Saussy explains in his last chapter, is to believe in "Hegel's China ... a realm of indifference that has to be understood in its difference from non-indifference (a difference that history has to consolidate before it can pronounce on it)" (183). 
This, too, is part of a project of undermining the authenticity claims that end up denigrating translation.

Saussy's Ethnography only briefly refers to Chinese literature, to detail how the then new oral theory allowed Marcel Granet "to imagine a social order that would account for both the form and the themes of the poetry" of the Shijing (2016, 28; see 27-33). Edward Shaughnessy has filled in the genealogy of the orality hypothesis as voiced by C. H. Wang and Granet - and by extension, Arthur Waley, whose translation The Book of Songs (1937) was thoroughly indebted to the work of Granet. But when it comes to translation, Shaughnessy as genealogist ends at a remove from Saussy's implications. Examining "the length and breadth of early China's paleographic record," he writes, the premises "concerning the creation and transmission of the Classic of Poetry become ever less persuasive, and the statements concerning the oral nature of the Poetry ... should be subject to re-evaluation" (2016, 146-147). Saussy's critique of the originary seems to have originated another postulation of certain origins.

In another paper Shaughnessy offers an example of the difference it makes to translation whether one believes that the Shijing was transmitted primarily orally or textually. Waley translates the poem Xia wu (下武) from the Daya (大雅) as “Footsteps Here Below." It begins:

Chou it is that continues the footsteps here below. 下武維周
世有哲王
三后在天
王配於京

From generation to generation it has had wise kings.

Three rulers are in Heaven,

He is their counterpart in his capital,

王配於京

The power of generations he has matched; 世德作求

Long has he been mated to Heaven's command 永言配命 And fulfilled what is entrusted to a king. 成王之孚

Has fulfilled what is entrusted to a king,

成王之孚

A model to all on earth below;

下土之式

Forever pious towards the dead, 永言孝思 A very pattern of piety. 孝思維則 
For Shaughnessy, it is "Descending from Wu," and starts:

Descending martially is Zhou, Generations have had wise kings!

The three lords are up in heaven

The king matches in the capital.

The king matches in the capital, Worldly virtue being a mate.

Eternal the matching mandate

The Completing King's trustfulness.

The Completing King's trustfulness

A model for the lands below.

Eternal the filial thoughts,

Filial thoughts are the standard.

$(2015,370-371)$

Certainly the differences between Waley and Shaughnessy as scholars and poets are not reducible to a disagreement over the orality of the Shijing. Nevertheless, "literary qualities" aside, Shaughnessy writes, "I am confident that mine better reflects the original structure and purpose of the poem." Furthermore, his "contribution derives from awareness of a range of bronze inscriptions from the Western Zhou dynasty" (2015, 372) - in other words, the written record. And yet, problematically - at least from the point of view of a critique of the authentic - Shaughnessy offers written transmission as its own authenticity, relying on the history and heritage of writing to produce what he thinks of as a reflection of "the original structure and purpose of the poem." At the theoretical level, he is only disagreeing with Waley, not sublimating or synthesizing his opposition.

Where to from here, then? Orality only needs to posit an authenticity from a Derridean perspective in which it is associated with logos and a metaphysics of presence. But what if this presence might itself be equally absent? What if a written oral can highlight the impermanence of both the oral and the written, just as translation might be able to highlight the translatedness of both source and target texts?

American poet Anthony Madrid does just that in his transcription of a translation mis-inscribed on his memory. Madrid was trying to recite his favorite Shijing poem to his students in Texas, "Thorn Vine on the Wall" (墻有茨), in Burton Watson's translation. It reads: 
Thorn vine on the wall must not be stripped: words in the chamber must not be told. What could be told would be the ugliest tale!

Thorn vine on the wall must not be pulled down: words in the chamber must not be recited. What could be recited would be the longest tale!

Thorn vine on the wall must not be bundled off: words in the chamber must not be rehearsed. What could be rehearsed would be a shameful tale!
墻有茨

不可掃也

中冓之言

不可道也

所可道也

言之醜也

墻有茨

不可襄也

中冓之言

不可詳也

所可詳也

言之長也

墻有茨

不可束也

中冓之言

不可讀也

所可讀也

言之辱也

(Watson 1984, 24)

"So the beauty of the thing," Madrid writes, "is they never tell you what happened in the chamber. But if those walls could speak ...!" His narrative style is irrefutably colloquial, oral - but of course it is written. Watson, meanwhile, only says of the Shijing poems that "Most, if not all, were intended to be sung, though the musical settings were lost long ago" (15), not necessarily embracing, I think, the orality hypothesis. And yet in Madrid's recitation, as transcribed, that is exactly where it goes. His memory was faulty. He writes,

I charged in with complete confidence, but found out right smartually that I was quite unable to retrieve the endings of any of the stanzas. So I just had to make it up as I went along ... But the crazy thing is, the invented stuff that came out of my mouth ... was good. The kids were impressed ... Cheggitout.

Thorn vine on the wall?

must not be stripped.

Words in the chamber ...? 
must not be repeated.

'Cuz what could be repeated ...?

Ugkh. You don't wanna know.

Thorn vine on the wall?

must not be taken down.

Words in the chamber ...?

Shhh. That's - not for you.

'Cuz what happened in that chamber ...?

[wag finger like no-no-no]

Uh-uh. Uh-uh.

Thorn vine on the wall?

must not be fucked with.

Words in the chamber ... uuuhhh.

'Cuz - that ...?

[waving hand in front of your nose in the Mexican manner of waving off a bad smell]

that? ... ooh, ugkh.

Madrid writes, "What came out of my mouth was basically a legitimate translation of what the poem says - it's just not word-for-word. In fact, part of what came out of my mouth wasn't even words ..." Yes, a legitimate translation. But for all that Madrid's words seem spoken, can we, in the end, even be sure that they ever were? He introduces his recitation, "Okay, so now here, carefully reconstructed, using archival footage and oral testimony of eyewitnesses, is what I said, whatever day that was, spring semester, 2017" (2017). Protesting too much, his orality argues against Saussy's contention that the category of "oral literature" asserts "what the work originally (despite the passage of time) and really (despite the words on the page) is." With this written translation of an oral interpretation of a written translation, we have a textual translation - a culturally inflected interlingual translation - that shows translation figuratively as movement between cultures.

\section{Translating the raw materials of dagong poetry}

But can Madrid provide a model for all translations, or even for all translations of the Shijing? Enjoyable as it may be, it does not get us at the culturally agreed-upon "real thing," even with the caveat that the real "real thing" 
cannot exist. In principle, we may agree with Eric Hayot that "literal interpretations are, just like allegorical ones, the products of a set of social interactions that involve language with power," therefore "any claim about the native 'integrity' of a text [cannot] be anything but the first and most oppressive metaphor" (2008, 124-125). But I think we are more likely to be left with Zhang's view, allowing the possibility of allegory but feeling that translation, at least, "must be based on the literal sense of the text."

Can we push further? Monica Zikpi's "response to Zhang” suggests

shifting the basis of cross-cultural understanding and translation from the hermeneutic unveiling of the "original intention" to a deeper, firmer grounding in a philology that accounts for the original's particular historical life, its pre-textual and extra-textual ways of being as well as its mutable material transmission and dynamic interpretive reception.

$(2016,20)$

Today, she writes, "the Shijing yields no 'original' literal sense, but it may translate (etymologically speaking, carry over) some guidelines for its interpretation" (4). So - can this be done with respect to dagong poetry?

As said above, the best argument for a poem's being not an authenticity but a translational process is a good translation. Given the distance between Shijing poetics and the contemporary, not all the philology Zikpi calls for is necessary in translating dagong poetry. Nevertheless, dagong poetry is as embedded as the Shijing in "pre-textual and extra-textual ways of being" (and the concomitant claims), so Zikpi's point still works. I want to argue that Goodman's translations fulfill this with respect to dagong poetry, that they bring out the translatedness of their source by foregoing the "hermeneutic unveiling of the 'original intention" in favor of an account of the poetry's "particular historical life ... its mutable material transmission and dynamic interpretive reception." But first I should note the discursive difficulty in arriving at such a point, because of the weight of the authenticity claim on the poetry in question.

We see this difficulty even in Goodman's own writing on dagong poetry. Explaining the context of her translations, she argues against "focusing on shenfen" 身份 - the authentic "identity" on which He Xuan compiled his anthology - to focus instead "on the notions of experience and material." She is struggling to "shift the emphasis from the poet to the poetry," yet her terms always revert to an authenticity that poetry readers in the West presumably lack: "Someone working in a coalmine or an electronics factory or a printshop has seen, heard, smelled, felt and done things that most of those who fit the 
conventional picture of a poet have not." The presentation of an authenticity behind, but also in, the poetry is ultimately what compelled her to accept the project: "it became clear to me that migrant worker poetry is made by important voices that should be heard, and that it reflects experience of a kind whose expression from an inside perspective is well worth the outsider's while" $(2017,112-113)$. Though she resists the common terminology of shenfen, she shares with critics like He a reliance on experience, voice, and whatever else makes one's identity authentic, rather than crafted - what the poetry, in Saussy's words, "originally (despite the passage of time) and really (despite the words on the page) is." At a deep level, this focus replays what Zhang calls the "dichotomy between natural manifestation and human creation" of "Chinese wen and Western literature," and rhetorically undermines the artistry of dagong poetry.

Too much of such an attitude also argues against the possibility of translation. If what the worker poets write is an authentic expression of their selves and experiences, then communicating that expression over too far a distance - such as in literary translation into English - would alienate those workers from the immediate conditions of their own lives. The translation would become all about serving the "outsider," at the expense (and the economic terminology is not accidental) of the laborers' "inside perspective." In translation, this attitude can be seen behind the stiffness of the versions by the blogger or bloggers called Nào 闹 (2014) of poems by Xu Lizhi 许立 志 (1990-2014), a Foxconn worker who killed himself. Insufficient attention to crafting a poetics in English implies either that $\mathrm{Xu}$ has no worthwhile poetics, or that his poetics must remain forever inaccessible beyond the translational border. From "I Swallowed a Moon Made of Iron" (我咽下一 枚铁做的月亮): “All that I've swallowed is now gushing out of my throat / Unfurling on the land of my ancestors / Into a disgraceful poem" (2014). The text seems to operate according to the idea that its essence has been lost in translation, betraying an idea of dagong poetry as "untranslatable" as defined above, measurable only in terms of loss of the authentic.

Goodman's disagreement about stiff renditions indicates a different attitude about Xu's authenticity. She writes about Nào's word choices:

The closed sound of "un" opening up into the long curl of the "furl" is very appealing ... The first thing I thought when I saw it was, I wish I'd thought of "unfurl"... it's relatively uncommon and has grand resonances, and it demonstrates that the translator has a rich vocabulary. And the original $p u$ 鋪 can legitimately be rendered as "unfurl," although its core meaning is "to pave." 
But she had second thoughts:

The Chinese verb is plain, not grandiose but ordinary ... there is also a problem in what one thinks is being unfurled. Ostensibly, it is a poem. A poem can be unfurled, if it's like a scroll, in some romantic Tang-dynasty image. But this hardly befits Xu Lizhi, who wrote in grungy notebooks. And what is implied in his poem is vomit ("gushing out of my throat"), which definitely can't be unfurled.

$(2017,114-115)$

Goodman's consideration of the word unfurl, from angles of poetics in English to appropriateness to the Chinese vocabulary and overall tone of the poem, demonstrates her sensitivity as both a reader and writer. And her change of mind about the vocabulary on which it hinges demonstrates her ability to make an account of dagong poetry's "pre-textual and extra-textual ways of being."

Goodman weighs contradictory impulses and brings them together into one work of art. It happens again when she writes that the "sensory data" the poets experience in the mine or the factory "may constitute the raw material that goes into a literary work" (112). That there is raw material means that there is work that goes into the literary work. Yet notably, this is not the only time the term appears in her paper: explaining her change of mind about the word unfurl, she quotes translation theorist Antoine Berman about the dangers of "ennoblement," "producing 'elegant' sentences, while utilizing the source text so to speak, as raw material. Thus the ennoblement is only a rewriting, a stylistic exercise based on - and at the expense of - the original" (Goodman 2017, 114). Berman, curiously, seems to want translation not to be work - or not, at any rate, overworked. Goodman, however, states on the one hand that poets can and should treat their sensory data of labor as raw material, but on the other that translators should not poeticize the raw material of their source texts to "ennoble" them. It sounds like a contradiction. But given her artistry, I think it is instead a resolution, bringing together the poem's "mutable material transmission and dynamic interpretive reception."

In her anthology, Goodman's translation, titled "I Swallowed an Iron Moon," reads:

I swallowed an iron moon they called it a screw 
I swallowed industrial wastewater and unemployment forms

bent over machines, our youth died young

I swallowed labor, I swallowed poverty

swallowed pedestrian bridges, swallowed this rusted-out life

I can't swallow any more

everything I've swallowed roils up in my throat

I spread across my country

a poem of shame

(Goodman 2016, 198)

\author{
我咽下一枚铁做的月亮 \\ 他们把它叫做螺丝 \\ 我咽下这工业的废水, 失业的订单 \\ 那些低于机台的青春早早天亡 \\ 我咽下奔波, 咽下流离失所 \\ 咽下人行天桥, 咽下长满水锈的生活 \\ 我再咽不下了 \\ 所有我曾经咽下的现在都从喉咙汹涌而出 \\ 在祖国的领土上铺成一首 \\ 耻辱的诗
}

(Qin 2015, 360)

Perhaps because Goodman brings forth the poem's "dynamic interpretive reception," this translation "raise[s] questions about the translations" for van Crevel. In his review of the anthology, he writes: "For line 4 ("bent over machines. ..'), 低于 in the original should probably be read as meaning 'lower than' rather than 'stooped over.'” And he wonders about "Goodman's use of 'I' in the penultimate line, as the subject of the poem's final sentence": "the absence of another 我 in the penultimate line and 成 in 铺 成 rather suggest something along these lines: 'I can't swallow any more / everything I've swallowed roils up in my throat /(/) and spreads across 
my country / a poem of disgrace'" (2017b). ${ }^{5}$ Are these questions marked by treating dagong poetry as the "authentic expression" that mars Nào's translations?

Van Crevel's criticisms come with a corollary made elsewhere:

For argument's sake, one could even maintain that the degree to which a text is conventionally considered untranslatable and requires rulebreaking is proportional to the potential for poetic translation ... And of course, if we really wanted the same thing as the original, we should discard translation altogether and shed the desire to know what gets said in other languages than the ones we speak.

(2017c, par. 116)

But no matter how good my Chinese may get, could discarding translation altogether ever give me "the same thing as the original"? Am I ever not reading in translation, when reading in a language I learned after childhood? The easy dichotomy between "poetic translation" and "the original," through the cracks of which fall a sense of poetry as translation - as translational in nature and forever engaged in translation - mirrors the discourse around dagong poetry in the literary field with respect to more safely literary poetics, the "crude opposition" between "social significance (high) and aesthetic value (low)" with which van Crevel is so impatient. Can we get to a point where we can see both aesthetics and social significance both in the poetry being translated and in the act of translation?

Though van Crevel's comments about a poem's "untranslatability" requiring rule-breaking demonstrates the complexity in his thinking about translation (and see his discussion of "content bias" in translation, in 2008, 284-288), his stance here is more scholarly than literary. It may even resemble Shaughnessy's attitude toward translation, above, based on the scholar's certainty of his own reading, rather than considering the theoretical inferences to be drawn from counterbalancing that certainty with a consideration of poetics in English. In other words, while van Crevel may be right that Xu's line probably means "lower than machines," is it better than "bent over machines" in conveying the artistry of poets who are menial laborers by trade? Can a translation be right, even if it's wrong?

5 The parenthesis around the virgule marks van Crevel's observation that different publications differ in printing the last four lines as comprising one stanza or two - which, he says, makes a difference to how we might understand the grammar of the clauses. 
While as theorists we might reject belief in the "real thing" of our source texts, as specialists and activists we seem to require it.

Yet this tension with van Crevel's approach to translation reaches resolution, too. It happens in Goodman's republication of the poem in an article on her translations. She takes van Crevel's suggestion to change "bent over machines" to "lower than machines": the linguistic accuracy enables the reader of the translation to sense that the humans may be worth less than the machines they operate. Likewise, she changes the final four lines - though not exactly as van Crevel suggested:

I can't swallow any more

everything I've swallowed roils up in my throat

to spread across my country

a poem of shame

$(2017,113)$

Whereas I said above that Shaughnessy only disagrees with Waley, but does not sublimate his opposition, Goodman's incorporation of van Crevel's alternate readings - his corrections - demonstrates what Zikpi calls the poetry's “mutable material transmission." Van Crevel's more positive comments, such as his praise for Goodman's "reflection on cultural difference" and knowing "when to honor the literal, and when to shun it," come to the fore. The poetry, he writes, "remains true to life in translation" (2017b).

\section{Art and work and the work of art}

The motto of this paper shows Bob Dylan asserting, in his preface to the song "Bob Dylan's Blues," his authenticity over the churned-out production of Tin Pan Alley lyrics. They "may not be pure folk songs," Saussy writes about the poems of the Shijing, "but calling them folk songs has its advantages." His words apply as well to Dylan's songs: "It is an economical move. If a folk song seems to be about poverty or elopement, it must be about poverty or elopement - or at least that is how the scholars view folk song" $(1993,59)$. But there is a cost to that economical move, if it means we overlook the expression as art and work ("which is not work unless it changes something," in Saussy's words). In the case of Dylan, the artistry and change give his words their irony and humor. By the time he recorded "Bob Dylan's Blues" in 1962, he had already established himself in Manhattan, and he was in a Columbia 
Records studio, just a mile and a half from Tin Pan Alley. Meanwhile, the song features not scenes from Dylan's own upbringing in iron-ore country, say, but the manufactured nostalgia of TV shows ("Well, the Lone Ranger and Tonto / They are ridin' down the line / Fixin' everybody's troubles / Everybody's except mine"). United States, indeed!

In premodern China literary writing "was recognizable through its high degree of intertextuality," Saussy points out in his most recent monograph, Translation as Citation. "A text that came into the world without this tissue of connection would give an impression of entire forgetfulness and utter nakedness" (2018, 94). Because the Shijing and dagong poetry seem to stand outside (before, after) that tradition, some have fantasized about their nakedness. But a better way to approach such poetry is as laying bare the kind of artistry and irony with which Dylan betrays his own claims of authenticity. This highlights how the poets of the Shijing and the migrant worker poets of dagong poetry are both working, and working in art. As Saussy writes, "translations are acts, not discoveries" (2001, 31). I have elaborated on how one of Goodman's translations embodies such action, mediating their mediations and translating their cultural translatedness. This means that when she writes of hoping her translations will give migrant workers "some kind of voice, a chance to articulate their own experiences, and to finally be heard - in Chinese, and in other languages" $(2017,126)$, she knows they already have a voice, and she knows it is a voice of both art and work.

\section{Works cited}

Chow, Rey. 1998. "Introduction: On Chineseness as a Theoretical Problem." Boundary $225(3): 1-24$.

Dylan, Bob. 1963. The Freewheelin' Bob Dylan. New York: Columbia Records.

Goodman, Eleanor, trans. 2016. Iron Moon: An Anthology of Chinese Worker Poetry, edited by Qin Xiaoyu. Buffalo: White Pine Press.

-. 2017. "Translating Migrant Worker Poetry: Whose Voices Get Heard and How?" Journal of Modern Literature in Chinese 14 (2)-15 (1): 107-127.

Hayot, Eric. 2008. Review of Allegoresis: Reading Canonical Literature East and West, by Zhang Longxi. Comparative Literature Studies 45 (1): 122-126.

-. 2011. "Vanishing Horizons: Problems in the Comparison of China and the West." In A Companion to Comparative Literature, edited by Ali Behdad and Dominic Thomas, 88-107. West Sussex: Wiley-Blackwell.

He Xuan 何轩. 2010. 《中国 “打工诗歌” 辑录与评点》 [A collection with critical commentary of Chinese "battlers poetry"]. Wuhan: Hubei renmin chubanshe. 
Klein, Lucas. 2017. "Strong and Weak Interpretations in Translating Chinese Poetry." Journal of Modern Literature in Chinese 14 (2)-15 (1): 7-43.

-. 2018. The Organization of Distance: Poetry, Translation, Chineseness. Leiden: Brill.

Liu, James J. Y. 1982. The Interlingual Critic: Interpreting Chinese Poetry. Bloomington: Indiana University Press.

Madrid, Anthony. 2017. “Thorn Vine on the Wall.” The Paris Review (blog), October 11, 2017. bit.ly/2YXY8eX. Accessed March 21, 2018.

Mair, Victor, and Tsu-Lin Mei. 1991. "The Sanskrit Origins of Recent Style Prosody." Harvard Journal of Asiatic Studies 51 (2): 375-470.

Nào 闹. 2014. "The Poetry and Brief Life of a Foxconn Worker: Xu Lizhi (1990-2014)." Libcom.org, October 29, 2014. bit.ly/1oMIgNC. Accessed March 22, 2018.

Owen, Stephen. 1985. Traditional Chinese Poetry and Poetics: Omen of the World. Madison: University of Wisconsin Press.

—. 1990. "What Is World Poetry? The Anxiety of Global Influence." New Republic 203 (21): 28-32.

—, ed. 1996. An Anthology of Chinese Literature: Beginnings to 1911. New York: W. W. Norton.

Qin Xiaoyu 秦晓宇, ed. 2015. 《我的诗篇: 当代工人诗典》 [My poems: the canon of contemporary workers poetry]. Beijing: Zuojia chubanshe.

Saussy, Haun. 1993. The Problem of a Chinese Aesthetic. Stanford: Stanford University Press.

-. 2001. Great Walls of Discourse and Other Adventures in Cultural China. Cambridge, MA: Harvard University Asia Center.

—. 2016. The Ethnography of Rhythm: Orality and Its Technologies. New York: Fordham University Press.

—. 2018. Translation as Citation: Zhuangzi Inside Out. Oxford: Oxford University Press.

Shaughnessy, Edward L. 2015. "Unearthed Documents and the Question of the Oral versus Written Nature of the Classic of Poetry." Harvard Journal of Asiatic Studies 75 (2): 331-375.

- 2016. "The Origin and Development of Western Sinologists' Theories of the Oral-Formulaic Nature of the Classic of Poetry." Bulletin of the Jao Tsung-i Academy of Sinology 3: 133-149.

van Crevel, Maghiel. 2008. Chinese Poetry in Times of Mind, Mayhem and Money. Leiden: Brill.

- 2017a. "The Cultural Translation of Battlers Poetry (Dagong Shige)." Journal of Modern Literature in Chinese 14 (2)-15 (1): 245-286.

-. 2017b. Review of Iron Moon: An Anthology of Chinese Migrant Worker Poetry, translated by Eleanor Goodman, edited by Qin Xiaoyu. MCLC Resource Center. bit.ly/2TejwbC. Accessed January 15, 2018. 
-. 2017c. "Walk on the Wild Side: Snapshots of the Chinese Poetry Scene." MCLC Resource Center. bit.ly/2GaWWhc. Accessed March 14, 2018.

-. 2019. "Misfit: Xu Lizhi and Battlers Poetry (Dagong Shige)." Prism: Theory and Modern Chinese Literature 16 (1): 85-114.

Waley, Arthur, trans. 1937. The Book of Songs. London: Allen \& Unwin.

Waley, Arthur, trans., Joseph R. Allen, ed. and trans. 1996. The Book of Songs: The Ancient Chinese Classic of Poetry. New York: Grove Press.

Wang, Dorothy J. 2014. Thinking Its Presence: Form, Race, and Subjectivity in Contemporary Asian American Poetry. Stanford: Stanford University Press.

Watson, Burton, ed. and trans. 1984. The Columbia Book of Chinese Poetry: From Early Times to the Thirteenth Century. New York: Columbia University Press.

Xunzi 荀子. 1988. 《荀子集解》 [The collected and explicated Xunzi], edited by Wang Xianqian 王先謙. Beijing: Zhonghua shuju.

Yip Wai-lim, ed. and trans. 1997. Chinese Poetry: An Anthology of Major Modes and Genres. Durham, NC: Duke University Press.

Yu, Pauline. 1987. The Reading of Imagery in the Chinese Poetic Tradition. Princeton: Princeton University Press.

Zhang Longxi. 2005. Allegoresis: Reading Canonical Literature East and West. Ithaca: Cornell University Press.

Zikpi, Monica E. M. 2016. “On Translation's ‘Original' and an Emergent Translation of the Shijing." Journal of Oriental Studies 49 (1): 1-25.

\section{About the author}

Lucas KLEIN (PhD Yale) is a father, writer, and translator, as well as associate professor in the School of Chinese at the University of Hong Kong. His translation Notes on the Mosquito: Selected Poems of Xi Chuan (New Directions, 2012) won the 2013 Lucien Stryk Prize, and his scholarship and criticism have appeared in Comparative Literature Studies, LARB, Jacket, CLEAR, $P M L A$, and other venues. Other publications include October Dedications, his translations of the poetry of Mang Ke (Zephyr and Chinese University Press, 2018); and contributions to Li Shangyin (New York Review Books, 2018); and the monograph The Organization of Distance: Poetry, Translation, Chineseness (Brill, 2018). His translations of the poetry of Duo Duo, forthcoming from Yale University Press, won him a PEN/Heim Translation Fund grant. 